\title{
THE EFFECT OF MELATONIN ON THE CATALASE AND THE BLOOD GLUTATHIONE TRANSFERASE ACTIVITY OF RATS IN CASE OF INTOXICATION WITH 2,4-DINITROPHENOL
}

\section{M.V. Dikal, I.V. Matsiopa, O.H. Cherniuh}

\begin{abstract}
Changes of the blood antioxidant enzymes have been inverstigated on albino nonlinear male rats with toxic poisoning by 2,4-dinitrophenol. It has been established that the catalase activity in the rat blood increased against a background of the intoxication. At the same time, the glutathione transferase activity under the conditions of 2,4-dinitrophenol intoxication decreased as compared with the control. The introduction of exogenous melatonin resulted in a correction of the blood indices under study, approximating them to the control values.
\end{abstract}

Key words: catalase, glutathione transferase, 2,4-dinitrophenol, rats.

Bukovinian State Medical University (Chernivtsi)

Рецензент - проф. Ю.С. Роговий
Buk. Med. Herald. - 2013. - Vol. 17, № 2 (66). - P. 46-48

Надійшла до редакції 04.04.2013 року

(C) М.В. Дікал, І.В. Мацьопа, О.Г. Чернюх, 2013

УДК 616.12-008.64-092-07

\author{
T.O. Ілащук
}

\section{ЦИТОКІНОВИЙ КАСКАД ТА БІОМАРКЕРИ ПОШКОДЖЕННЯ МІОКАРДІОЦИТІВ У КОНТИНУУМІ ГОСТРОЇ СЕРЦЕВОЇ НЕДОСТАТНОСТІ ТА ІНФАРКТУ МІОКАРДА}

Буковинський державний медичний університет, м. Чернівці

Резюме. 3 метою вивчення клінічних особливостей перебігу гострого інфаркту міокарда, ускладненого гострою лівошлуночковою недостатністю різних ступенів тяжкості, обстежено 368 пацієнтів. Виділено ряд особливостей перебігу захворювання у сформованих групах пацієнтів.

Ключові слова: гострий інфаркт міокарда, гостра лівошлуночкова недостатність, перебіг, ускладнення.
Вступ. Згідно $з$ представленими в «Statistical Fact Sheet - Populations 2007 Update» даних, 17,7 млн людей щорічно вмирає у світі від серцевосудинних захворювань (СС3), як мінімум 20 млн пацієнтів переносять серцеві напади і інсульти щороку $[1,2]$. В Свропі страждають від стенокардії 20.000-40.000 осіб на млн населення, від СС3 щорічно вмирає 4,35 млн у Свропі і 1.9 млн у Євроспільноті. Згідно з даними Американської асоціації серця та аналізу «Heart Disease and Stroke Statistics - 2010 Update», один із трьох американців має більш одного СС3, коронарна хвороба серця (КХС) реєструється в 16.800 .000 , стенокардія - у 9.800.000, підвищений артеріальний тиск - у 73.600.000, інфаркт міокарда (IM) - у 7.900.000, щорічно в США відбувається 1,57 млн госпіталізацій за розвитку гострого коронарного синдрому (ГКС), серцева недостатність $(\mathrm{CH})-\mathrm{y}$ 5.700.000, інсульт - у 6.500 .000 пацієнтів, кожні 38 с вмирає один американець, а кардіоваскулярна смерть відповідає за один із 2,9 випадка, у тому числі КХC - за 1 із 6 випадків, $\mathrm{CH}$ - за 1 із 8,6 випадка. Кожні 7 хв один канадець вмирає від СС3. В Україні 11,7 млн - хворі на АГ та 8,5 млн - на ішемічну хворобу серця (IXC), смертність від IXC в Україні у 2-3 рази вища, ніж у Свропі $[2,6]$.

(c) Т.О. Ілащук, 2013

48
Мета дослідження. Вивчити клінічні особливості перебігу ГІМ, ускладненого гострою лівошлуночковою недостатністю (ГЛШН) різних ступенів тяжкості.

Матеріал і методи. Обстежено 368 пацієнтів, які надійшли у блок кардіореанімації Чернівецького обласного кардіологічного диспансеру. Аналіз результатів клінічного спостереження проводився з урахуванням класу ГСН за Т. Killip. Так, ознаки ГСН Killip I реєструвались у 117 (31,79 \%) пацієнтів, Killip II - у 115 (31,25\%), Killip III - у $89(24,19 \%)$ та Killip IV - у 47 $(12,77$ \%) хворих на ГІМ. Усім обстеженим пацієнтам на початку та після закінчення лікування в динаміці 28 діб спостереження проведено оцінку вмісту прозапальних цитокінів (інтерлейкіну-1- $\alpha$ (Іл-1- $\alpha)$, інтерлейкіну-6 (Іл-6), інтерлейкіну-10 (Іл-10), тумор некротичного фактору (ТНФ), неоптерину (Нп)), біомаркерів пошкодження міокарда (тропоніну-I (Tp-I)), С-реактивного протеїну (СРП) та чоловічого статевого гормону тестостерону (Тст) методом імуноферментного аналізу. Математичний аналіз отриманих результатів проводився з оцінкою середнього значення, стандартної похибки середнього, вірогідність кількісних параметрів визначена в межах перевірки «нульової гіпотези» 3 використанням t-критерію Стью- 
дента 3 оцінкою за рівня значущості для $\mathrm{p}<0,05$ (при використанні парного t-критерію Стьюдента для аналізу у двох залежних вибірках при рівномірному розподілі масивів та t-критерію Вілкоксона - при нерівномірному розподілі масивів; у двох незалежних вибірках при рівномірному розподілі двовибіркового t-критерію Стьюдента, двох незалежних вибірках при нерівномірному розподілі - U-критерію Вілкоксона).

Результати дослідження та їх обговорення. Гендерний аналіз показав, що кількість чоловіків переважала в усіх чотирьох групах, причому у співвідношенні чоловіки / жінки число чоловіків збільшувалося зі зростанням класу ГСН. Так, у групі Killip I 61,54 \% становили чоловіки й 38,46 \% - жінки; Killip II - 71,31 \% припадав на чоловіків, 28,69 \% - на жінок; Killip III - 73,04 \% та 26,96 \%; Killip IV - 85,11 \% та 14,89 \% чоловіків та жінок відповідно. Віковий аналіз показав, що в групі Killip I середній вік пацієнтів складав $59,3 \pm 0,96$ року, Killip II - 61,7+0,67 року, Killip

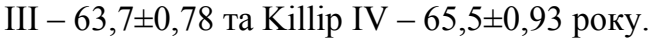

Аналіз розподілу Q- неQ-форм IM у обстежених пацієнтів показав, що в пацієнтів із ГСН Killip I Q-IM реєструвався в 69,23 \% випадків, а HeQ-IM - у 30,77 \%; ГCH Killip II - у 84,34 \% та $15,66 \%$; ГCH Killip III - у 93,26 \% та 6,74\%; ГСН Killip IV - у 95,74 \% та 4,26\% Q- та неQформи IM відповідно. Отже, можна дійти висновку, що ГСН частіше розвивається в пацієнтів із Q-формами ГIM, причому найчастіше Q-IM peєструється серед пацієнтів із ГСН Killip III та ГCH Killip IV, що збігається 3 даними інших дослідників [2]. Щодо розподілу локалізації ураження в обстежених пацієнтів виявлено наступні закономірності: передня стінка ЛШ у пацієнтів із ГCH Killip I була уражена в 58,12 \% випадків, Killip II - y 45,22 \%, Killip III - у 52,81 \% та Killip IV - у 55,32 \% пацієнтів; зміни по задній стінці ЛШ були зафіксовані в 40,17\% осіб із ГСН Killip I, 53,91\% - при Killip II, 48,31\% - Killip III та 44,68 \% - при Killip IV; зміни в ділянці перегородки реєструвалися 3 наступною частотою: $52,99 \%, 37,39 \%, 43,82 \%$ та 42,55 \% при ГСН Killip I, Killip II, Killip III та Killip IV відповідно. Окрім того, ураження верхівки та бічної стінки в пацієнтів із ГСН Killip I спостерігалось у 46,15 \% та $20,51 \%$, Killip II - 32,17 \% та 22,61 \%, Killip III - 37,08 \% та 26,97\%, Killip IV - 38,29\% та $15,15 \%$ випадків відповідно. Таким чином, спостерігається збільшення частоти реєстрації ГІМ передньої стінки ЛШ у пацієнтів з більш тяжким перебігом ГСН.

Наявність ознак післяінфарктного кардіосклерозу на ЕКГ та попередній IM в анамнезі зареєстровано в 16,24 \% пацієнтів із ГСН Killip I, $20 \%$ хворих на ГСН Killip II, 24,72\% - ГСН Killip III та 23,4 \% - ГCH Killip IV. Отримані дані дозволяють дійти висновку, що перебіг ГСН стає тяжчим за наявності післяінфарктного кардіосклерозу в анамнезі. Ці дані узгоджуються 3 іншими дослідженнями [5], де доведено, що післяінфарктний кардіосклероз є найбільш частою формою ішемічного ремоделювання міокарда, причиною розвитку $\mathrm{CH}$, порушень ритму та раптової смерті.

Аналіз летальності впродовж 28 днів перебування пацієнтів у стаціонарі в зівставленні з класом ГСН показав, що серед осіб із ГСН Killip I летальність становила 0 \%, тобто не померло жодного хворого, що може пояснюватися випадковістю вибірки, а також неускладненим перебігом ГІМ та вчасною, адекватною медикаментозною терапією. Серед пацієнтів із ГСН Killip II показник летальності становив 10,43\% $\%(\mathrm{p}<0,001)$, ГСН Killip III - 51,69\% $(\mathrm{p}<0,001)$, ГСН Killip IV $80 \%(\mathrm{p}<0,001)$. Спостереження впродовж одного року після перенесеного ГІМ, ускладненого ГСН, показало, що показник летальності в групі Killip I дорівнював 0,85 \%, Killip II - 0,86 \%, Killip III $24,72 \%$, Killip IV - 11,11 \%. Таким чином, загальний показник летальності становив при ГСН Killip I - 0,85 \%, ГСН Killip II - 11,29\% $(p<0,001)$, ГСН Killip III - 76,41\% $(p<0,001)$, Killip IV - 91,11\% ( $<<0,001)$, що збігається з даними інших дослідників.

На наступному етапі проаналізовано значення середнього рівня біомаркерів запалення та некрозу серцевого м'яза в обстежених пацієнтів залежно від класу ГЛШН. Відомо, що запалення відіграє неабияку роль у патогенезі ГІМ, а маркери системного запалення, активація яких пов'язана $з$ нестабільністю атеросклеротичної бляшки, можуть використовуватися для оцінки госпітального перебігу ГІМ та віддаленого прогнозу [2, 4, $5,6]$. Результати чисельних досліджень свідчать про негативний вплив С-реактивного протеїну (СРП), туморнекротичного фактора (ТНФ), інтерлейкінів та інших маркерів запалення на перебіг ГІМ у госпітальний період та на віддалені результати лікування цих хворих [3]. Для зручності порівняння обстежені пацієнти були розподілені наступним чином: група 1 - пацієнти без видимих клінічних ознак ГЛШН та група 2 - пацієнти 3 вираженими проявами ГЛШН (Killip II - IV). Порівнювалися міжгрупові рівні досліджуваних біомаркерів та внутрішньогрупова динаміка цих показників у процесі лікування. Отже, рівень Іл1- $\alpha$ значно перевищував нормативні значення в обох групах і був вірогідно вищим у пацієнтів групи 2 порівняно 3 пацієнтами групи 1

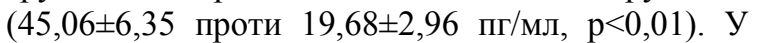
процесі лікування відмічалося вірогідне зменшення цього показника в обох групах, однак у групі 2 він залишався вірогідно вищим, аніж у

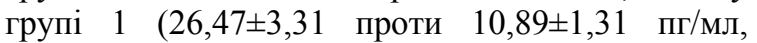
$\mathrm{p}<0,01)$. Отже, зменшення рівня Іл-1- $\alpha$ в групі 1 становило $\Delta \%-44,66 \%, \mathrm{p}<0,01$, а в групі $2-\Delta \%$ $-41,25 \%, \mathrm{p}<0,02$.

Аналіз вмісту Іл-6 показав, що його загальний рівень був значно вищим за нормативний показник в обох групах, причому в групі 2 його значення вірогідно більше порівняно 3 групою 1 $(45,69 \pm 7,1$ проти 13,14 $\pm 3,05$ пг/мл, $p<0,01)$. Упродовж 28 днів перебування пацієнтів у стаціонарі 
відбувалося вірогідне зменшення рівня Іл-6 в обох групах, але в осіб із клінічно вираженими ознаками ГЛШН значення його залишалося вірогідно вищим $(9,42 \pm 1,46$ проти $3,23 \pm 1,12$ пг/мл, $\mathrm{p}<0,01)$. Таким чином, зменшення показника Іл-6 у групі 1 становило $\Delta \%-75,49 \%, \mathrm{p}<0,01$, а в групі $2-\Delta \%-79,38 \%, \mathrm{p}<0,01$.

Вміст протизапального цитокіну Іл-10 в обох групах вірогідно не розрізнявся ні в першу добу

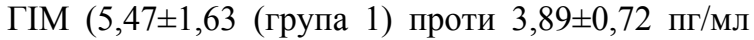
(група 2), p>0,5), ні на фоні лікування $(2,77 \pm 0,38$ проти 2,45 $\pm 0,42$ пг/мл, p $>0,5$, у групі 1 та групі 2 відповідно). Вірогідних змін внутрішньогрупового рівня цього показника в процесі лікування та-

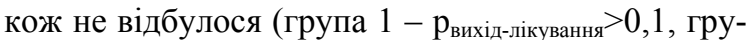
па $2-$ p вихід-лікування $>0,05)$.

На наступному етапі нами проаналізовано внутрішньо- та міжгрупові зміни рівня ТНФ упродовж 28 днів лікування. Отже, вихідний рівень ТНФ в обох групах перевищував нормативні значення, але в групі 2 був вірогідно вищим, ніж у групі 1 (59,12 $\pm 3,08$ проти 42,85 $\pm 2,22$ пг/мл, $\mathrm{p}<0,01)$. Після лікування відбулося вірогідне зменшення рівня ТНФ в обох групах, але в групі 2 цей показник залишався несуттєво більшим порівняно 3 групою $1(21,02 \pm 1,34$ проти $18,69 \pm 1,07$ пг/мл, $\mathrm{p}>0,1)$. Таким чином, зменшення показника ТНФ у групі 1 становило $\Delta \%-55,75 \%$ $(\mathrm{p}<0,001)$, а в групі $2-\Delta \%-64,45 \%(\mathrm{p}<0,001)$.

Отже, аналіз вмісту прозапальних цитокінів Іл-1- $\alpha$, Іл-6 та ФНП і протизапального цитокіну Іл-10 у пацієнтів із ГІМ, перебіг якого ускладнився ГЛШН, показав, що в пацієнтів обох груп спостерігається значне збільшення, порівняно 3 нормою, рівнів Іл-1- $\alpha$, Іл-6 та ТНФ, причому в пацієнтів із клінічно вираженими проявами ГЛШН всі три показники були вірогідно більшими, ніж у пацієнтів без клінічних ознак ГЛШН.

На наступному етапі дослідження нами проаналізовано, яким чином змінювалися середні значення Нп упродовж 28 діб перебування пацієнтів у стаціонарі. Виявлено, що рівень Нп перевищував нормативний в обох групах, причому в групі 2 він був вірогідно більшим порівняно 3 групою 1 (23,82 $\pm 4,15$ проти 12,02 $\pm 2,8$ нмоль/л, $\mathrm{p}<0,05)$. Через 28 діб відбулося вірогідне зменшення рівня Нп в обох групах, але в групі 2 цей показник залишався вірогідно більшим порівняно

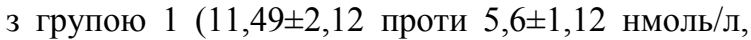
$\mathrm{p}<0,02)$. Отже, зменшення показника Нп у групі 1 становило $\Delta \%-53,41 \%(\mathrm{p}<0,05)$, а в групі $2-$ $\Delta \%-51,76 \%(\mathrm{p}<0,01)$.

Метаболіти Нп є антиоксидантами, підсилюють апоптоз клітин, а сам Нп відіграє певну роль у цитотоксичній дії активованих макрофагів. Його концентрація відображає сумісну дію різних цитокінів на популяцію моноцитів / макрофагів [2]. Отже, збільшення концентрації Нп супроводжується ускладненим перебігом серцевосудинних захворювань загалом та ГІМ зокрема [4], що цілком відповідає отриманим нами даним.
Аналіз погрупового рівня Тр-І показав його вірогідне збільшення у пацієнтів групи 2 порівняно 3 групою $1 \quad(37,41 \pm 6,49$ проти $25,52 \pm$ 4,22 нг/мл, $<<0,01)$. На 28-му добу ГІМ рівень ТрI залишався вірогідно вищим у пацієнтів групи 2 порівняно 3 групою $1(1,71 \pm 0,06$ проти $0,66 \pm$ $0,02$ нг/мл, $\mathrm{p}<0,001)$. Зменшення рівня Тр-І у групі 1 становило $\Delta \%-96,93 \%(\mathrm{p}<0,001)$, а в групі $2-\Delta \%-95,42 \%(\mathrm{p}<0,01)$.

Розбіжності середніх значень СРП в обох групах були вірогідними на виході $(0,11 \pm 0,02$ (група 1) проти $0,17 \pm 0,02$ (група 2) мг/л, p<0,05) та невірогідними на фоні лікування $(0,05 \pm 0,01$ проти $0,07 \pm 0,02$ мг/л, p>0,5 у групі 1 та 2 відповідно). Однак зменшення показника вірогідне як у групі $1(\Delta \%-54,55 \%, \mathrm{p}<0,02)$, так і в групі 2 $(\Delta \%-58,82 \%, \mathrm{p}<0,01)$.

На наступному етапі вивчався вміст чоловічого статевого гормону Тст у пацієнтів 3 ускладненим та неускладненим перебігом ГСН. Нами виявлено, що рівень Тст вірогідно вищий у пацієнтів групи 2 як на виході $(3,45 \pm 0,47$ проти $1,86 \pm 0,24$ нг/мл, $\mathbf{p}<0,01)$, так і після проведеного лікування $(3,24 \pm 0,36$ проти $1,5 \pm 0,22$ нг/мл, $\mathrm{p}<0,01)$. Вірогідних змін показника в процесі лікування не відбулося ні в групі 1 (p>0,2), ні в групі 2 ( $>>0,5)$.

Отже, у пацієнтів групи 2 середній рівень Tp-I та СРП вірогідно більший, ніж у пацієнтів групи 1. Отримані нами дані збігаються з даними інших авторів, які вказують на те, що збільшення цих показників свідчить про більш тяжкий перебіг ГІМ [6]. Оскільки Тст є гормоном «агресії», збільшення його середнього рівня носить несприятливий прогностичний характер $[1,3]$.

\section{Висновок}

Чоловіча стать, старший вік, передня локалізація IM, наявність післяінфарктного кардіосклерозу в анамнезі $\epsilon$ незалежними предикторами більш тяжкого перебігу ГЛШН. У той же час клінічно виражена ГЛШН характеризується більш високим рівнем прозапальних цитокінів (Іл-1- $\alpha$, Іл-6, ТНФ, Нп), Тр-І, СРП та Тст порівняно 3 неускладненим перебігом ГІМ.

Перспективи подальших досліджень. Не викликає сумнівів необхідність продовження пошуку нових підходів до діагностики та лікування ГЛШН, що сприятиме зменшенню смертності та покращанню прогнозу у хворих на ГІМ.

\section{Література}

1. Амосова Е.Н. Лечение инфаркта миокарда с элевацией сегмента ST. Основные положения рекомендаций Американского кардиологического колледжа и Американской ассоциации кардиологов - 2004 (Часть I) / Е.Н. Амосова, Л.А. Ткаченко // Серце і судини. 2005. - № 2. - C. 19-26.

2. Клініко-інструментальні маркери оцінки несприятливого перебігу госпітального періоду гострого інфаркту міокарда / О.М. Пархоменко, О.С.Гур'єва, О.В. Шумаков [та ін.] // Укр. кардіол. ж. - 2005. - № 6. - С. 10-18.

3. Оценка изменений уровня цитокинов, сывороточного неоптерина и С-реактивного белка у больных инфарк- 
том міокарда / Г.Е. Кубенский, С.А.Чернов, С.В. Скворцов [и др.] // Росс. кардиол. ж. - 2005. № 5. - C. 12-15.

4. Armstrong E.J. Inflammatory biomarkers in acute coronary syndromes. Part I: Introduction and cytokines / E.J. Armstrong, D.A. Morrow, M.S. Sabatine// Circulation. - 2006. - Vol. 113, № 6. - P. e72-e75.

5. Interleukin- 6 and the risk of future cardiovascular events in patients with angina pectoris and/or healed myocardial in- farction / E.Z. Fishman, M. Benderly, R.J. Esper [et al.] // Am. J. Cardiol. - 2012. - Vol. 98, № 1. - P. 14-18.

6. Prognostic implications of increased cardiac biomarkers and ST segment depression in non-ST elevation acute coronary syndromes: lessons from the acute coronary syndrome Israeli survey (ACSIS) / I. Ben-Dor, D. Hasdai, S. Behar [et al.] // Heart. - 2011. - Vol. 92, № 4. - P. 547-548.

\section{ЦИТОКИНОВЫЙ КАСКАД И БИОМАРКЕРЫ ПОВРЕЖДЕНИЯ МИОКАРДИОЦИТОВ В КОНТИНУУМЕ ОСТРОЙ СЕРДЕЧНОЙ НЕДОСТАТОЧНОСТИ И ИНФАРКТА МИОКАРДА}

\section{Т.А. Илащук}

Резюме. С целью изучения клинических особенностей течения острого инфаркта миокарда, осложненного острой левожелудочковой недостаточностью разной степени тяжести, обследованы 368 пациентов. Выделен ряд особенностей течения заболевания в сформированных группах пациентов.

Ключевые слова: острый инфаркт миокарда, острая левожелудочковая недостаточность, течение, осложнения.

\section{CYTOKINE CASCADE AND BIOMARKERS OF MYOCARDIOCYTES DAMAGE IN THE CONTINUUM OF ACUTE HEART FAILURE AND MYOCARDIAL INFARCTION}

\section{T.O. Ilashchuk}

Abstract. For the purpose of studying the clinical specific characteristics of the course of acute myocardial infarction complicated by acute left ventricular failure of diverse degrees of severity 368 patients have been examined. A number of features of the disease course in formed groups of patients have been singled out.

Key words: acute myocardial infarction, acute left ventricular failure, course, complications.

Bukovinian State Medical University (Chernivtsi)

Рецензент - проф. Л.П. Сидорчук

Buk. Med. Herald. - 2013. - Vol. 17, № 2 (66). - P. 48-51

Надійшла до редакції 24.01.2013 року

(C) Т.О. Ілащук, 2013

УДК 616.211/.231-002.1-022:616.226-002]-053.4-085.37

Т.О. Кірсанова, С.В. Кузнєцов, М.С. Зіміна, Е.В. Супрун

\section{ЕФЕКТИВНІСТЬ БАКТЕРІАЛЬНИХ ЛІЗАТІВ У КОМПЛЕКСНІЙ ТЕРАПІЇ ДІТЕЙ РАННЬОГО ВІКУ 3 ВІРУСНИМИ КРУПАМИ}

Харківський національний медичний університет

Резюме. У статті представлені результати вивчення особливостей цитокінового статусу та показників місцевого імунітету дітей із гострою респіраторною вірусною інфекцією, яка проходить із проявами синдрому крупу, та оцінка ефективності використання в комплексному лікуванні дітей бактеріальних лізатів. Доведено, що набряковий та гіперсекреторний варіанти синдрому крупу проходять на фоні значної інтенсифікації системної запальної відповіді та зниження факторів місцевого імунітету, а спазматичний варіант синдрому крупу розвивається на фоні фізіологічного рівня цитокінів і підвищення факторів місцевого імунітету в гострому періоді. Використання бактеріальних лізатів у комплексній терапії осіб із набряковим варіантом синдрому крупу супроводжується незначним зниженням рівня цитокінів, тоді як при гіперсекреторному варіанті вміст цитокінів знижується майже в 4-5 разів. На фоні прийому бактеріальних лізатів при набряковому варіанті синдрому крупу активність та вміст факторів місцевого імунітету дещо підвищується, але їх рівень залишається нижче показників контрольної групи, при гіперсекреторному варіанті їх рівень досягає показників здорових дітей. Результати дослідження дозволяють рекомендувати бактеріальні лізати до використання в комплексній терапії хворих на гіперсекреторний варіант синдрому крупу, що сприятиме більш швидкій нормалізації системної запальної реакції й стимуляції продукції та активації факторів місцевого імунітету у хворих дітей.

Ключові слова: вірусний круп, цитокіни, місцевий імунітет, діти, бактеріальні лізати.

(C) Т.О. Кірсанова, С.В. Кузнєцов, М.С. Зіміна, Е.В. Супрун, 2013 